\title{
Soil Moisture Adequacy Index (SMAI) of Jamner and Padalsare stations of Jalgaon district
}

\author{
V.N. Nale, S.P. Nikam and K.B. Patil
}

Received : 06.01.2020; Revised : 25.02.2020; Accepted : 10.03 .2020

See end of the Paper for authors' affiliation

Correspondence to :

S.P. Nikam

Department of Agricultural

Engineering, College of

Agriculture (MPKV),

Muktainagar, Dhule (M.S.)

India

Email: spnikam74@gmail.com
-ABSTRACT : Water is limiting factor for crop production and development. The success of dry land farming mainly depends on the evenly distributed rainfall during crop growing period when the rainfall before insufficient to meet the potential needs of transpiration, the root zone of soil moisture is utilized for transpiration. This causes soil moisture storage and a situation, which may be designed as group drought occurs. Water deficit study is one of the important aspects in rainfed farming as well as in water resource planning management and allocation of irrigation water studies on water deficit pattern during different year would provide basic information for evaluating climate potential of an area for agriculture planning and development. Soil moisture plays an important role in crop productivity besides weather parameters in rainfed in general and drought prone areas of Jalgaon district in particular, plants survive on available water of the soil. Soil Moisture Adequacy Index above $25 \%$ is found from $23^{\text {rd }} \mathrm{MW}$, it is $100 \%$ in $22^{\text {nd }} \mathrm{MW}$ at Jamner station. The average weekly rainfall is available predominantly from $23^{\text {rd }} \mathrm{MW}$ at Jamner station in Kharif and $41^{\text {st }} \mathrm{MW}$ at Rabi season. Soil Moisture Adequacy Index above $25 \%$ from $23^{\text {rd }} \mathrm{MW}$ and found to be $100 \%$ in $51^{\text {st }} \mathrm{MW}$ at Padalsare station. The average weekly rainfall is available predominantly from $25^{\text {th }} \mathrm{MW}$ at Padalsare station in Kharif and $41^{\text {st }} \mathrm{MW}$ at Rabi season.

- KEY WORDS : Soil moisture adequacy index

- HOW TO CITE THIS PAPER : Nale, V.N., Nikam, S.P. and Patil, K.B. (2020). Soil Moisture Adequacy Index (SMAI) of Jamner and Padalsare stations of Jalgaon district. Internat. J. Agric. Engg., 13(1) : 90-95, DOI: 10.15740/HAS/IJAE/13.1/90-95. Copyright@ 2020: Hind AgriHorticultural Society. 